\title{
Serology with ML Flow test in health professionals from three different states of Brazil ${ }^{*}$
}

\author{
Sorologia com o teste ML Flow em profissionais de saúde em \\ três diferentes estados do Brasil
}

\author{
Karla Lucena Sampaio Calado ${ }^{1}$ \\ Rodrigo Scaliante de Moura ${ }^{3}$ \\ Samira Bührer-Sékula ${ }^{5}$
}

\author{
Mônica Maria Ferreira Magnanini² \\ Maria Eugenia Noviski Gallo ${ }^{4}$ \\ Maria Leide Wand-Del-Rey de Oliveira ${ }^{6}$
}

DOI: $h$ ttp://dx.doi.org/10.1590/abd1806-4841.20132139

\begin{abstract}
BACKGROUND: In highly endemic countries, transmission and sub-clinical infection of leprosy are likely and the disease manifests itself in individuals without any known close contact with a leprosy patient. Health workers are social contacts belonging to the same network (the Health System) and some of them share the same social environment (nursing assistants) as patients with known patients and / or carriers. OBJECTIVE: To identify ML Flow seropositivity among health professionals. METHODS: We conducted a cross-sectional study using a serological survey with the ML Flow test in 450 health professionals (doctors, nurses and nursing assistants), in order to detect seropositivity in areas of high and low endemicity in municipalities from three Brazilian states (RJ, MS and RS). ResulTs: The results showed general 16\% seropositivity, higher in low endemic areas, regardless of whether there was direct care for leprosy patients. Paradoxically, a statistical association was observed between the area studied and seropositivity, as the place with the lowest endemicity $(\mathrm{CA})$ had the highest seropositivity rate $(\mathrm{p}=0.033)$. CONCLUSION: The authors suggest these results are associated with a presence of an unspecified link to bovine serum albumin (BSA), carrier of PGL-1 in the ML Flow test, and recommend expanded seroepidemiological research utilizing tests with human and bovine albumin.
\end{abstract}

Keywords: Education, public health professional; Health personnel;Health systems; Leprosy; Serologic tests; Unified health system

Resumo: FundAMENTOS: Em países altamente endêmicos a transmissão e infecção sub-clínica da hanseníase provavelmente ocorrem e a doença se manifesta em indivíduos sem qualquer contato próximo conhecido com paciente com hanseníase. Os trabalhadores de saúde são contatos sociais que pertencem à mesma rede (Sistema de Saúde) e alguns deles compartilham o mesmo ambiente social (auxiliares de enfermagem) com pacientes conhecidos e/ ou portadores. OBJETIVO: Conhecer a soropositividade ao ML Flow entre os profissionais de saúde. MÉToDOs: Foi realizado um estudo transversal através de inquérito sorológico com o teste ML Flow em 450 profissionais de saúde (médicos, enfermeiros e auxiliares de enfermagem) visando conhecer a soropositividade em áreas de alta e baixa endemicidade em municípios de três estados brasileiros (RS, MS e RJ). REsulTADOs: Os resultados mostraram 16\% de soropositividade em geral, mais elevada na área de baixa endemicidade, independente da assistência direta a pacientes com hanseníase. Paradoxalmente foi observada associação estatística entre a área estudada e soropositividade, apontando o lugar de mais baixa endemicidade (CA) com o maior valor $(\mathrm{p}=0,033)$. ConCLUsão: os autores sugerem a presença de ligação inespecífica a soroalbumina bovina (BSA), carreadora do antígeno PGL-1 no teste ML Flow para explicar os resultados inesperados e recomendam testagem ampliada utilizando testes com albumina humana e bovina.

Palavras-chave: Educação profissional em saúde pública; Hanseníase; Pessoal de saúde; Sistemas de saúde; Sistema Único de Saúde; Testes sorológicos

Received on 18.09.2012.

Approved by the Advisory Board and accepted for publication on 11.01.2013.

* Work performed at the Faculdade de Medicina Universidade Federal do Rio de Janeiro (UFRJ) - Rio de Janeiro (RJ), Brazil.

Financial support: The tests were provided by the National Health Foundation.

Conflict of interests: None.

Master's in Dermatology, Federal University of Rio de Janeiro (UFRJ) - Assistant Professor of Dermatology, Federal University of Grande Dourados (UFGD). $\mathrm{PhD}$ in Tropical Medicine from the Oswaldo Cruz Foundation (FIOCRUZ) - Rio de Janeiro (RJ), Brazil.

PhD in Public Health from the Oswaldo Cruz Foundation (FIOCRUZ). Statistics, Federal University of Rio de Janeiro (UFRJ) - Rio de Janeiro (RJ), Brazil.

Biomedical doctor. Master's in Tropical Medicine, Federal University of Goiás (UFG) - Goiânia (GO), Brazil.

PhD in Tropical Medicine from the Oswaldo Cruz Foundation (FIOCRUZ). Professor at the Oswaldo Cruz Foundation (FIOCRUZ) - Rio de Janeiro (RJ), Brazil.

PhD in Immunology from the Universiteit van Amsterdam, Netherlands - Collaborating Professor at the Federal University of Goiás (UFG) - Goiânia (GO), Brazil.

6 PhD in Dermatology from the Federal University of Rio de Janeiro (UFRJ)-Federal Adjuct Professor, University of Rio de Janeiro (UFRJ), Rio de Janeiro (RJ),

Brazil.

(C)2013 by Anais Brasileiros de Dermatologia 


\section{INTRODUCTION}

Despite its high infectivity, probably due to low pathogenicity, biosafety norms for leprosy are hardly discussed in health services, unlike the tuberculosis program. ${ }^{1,2}$ In addition, the known stigma associated with leprosy makes it difficult to know the actual number of health workers (HW) with the disease. They are considered social contacts of their patients, as some of them belong to the same network (the Health System). However, the multifactorial causes related to leprosy minimize the perceived risk among leprosy workers, in addition to the other reasons mentioned above. The detection of antibodies to Mycobacterium leprae (M. leprae) is potentially useful in epidemiological studies of infection with $M$. leprae. There is sufficient evidence on the use of serological tests as a tool for identification of patients with indirect $M$. leprae in the population. Further, PGL 1 serology has been suggested as an important auxiliary tool for the differentiation of paucibacillary leprosy (PB) and multibacillary leprosy (MB) ${ }^{3,4}$ Contacts of leprosy patients are known to have higher seropositivity. ${ }^{5,6,7}$ However, its application as an aid in the diagnosis of all clinical forms of leprosy is limited to MB forms. ${ }^{8}$ The antigen used is a semi-synthetic analog of phenolic glycolipid 1 (PGL-1), linked to bovine serum albumin (NT-P-BSA). ${ }^{910,11}$ Although the antigen is highly specific, (i) it was observed that seropositivity in children of school age and prevalence of leprosy were not correlated; (ii) in areas of high endemicity there were no differences in the proportion of seropositivity among contacts and non-contacts. ${ }^{12}$ These discordant results of the tests indicate that there remain unexplained factors and further research will help to clarify how the specificity of the test can be improved. ${ }^{13,14}$ This study aims to identify ML Flow seropositivity among health professionals.

\section{METHODS}

We conducted an exploratory, cross-sectional study via a serological survey in $450 \mathrm{HW}$ (doctors, nurses and nursing assistants) in order to know their seropositivity status in areas of high and low endemicity, at health units in different cities across three states: Cruz Alta (CA) in Rio Grande do Sul, low detection rate and endemicity of leprosy $(1.44 / 100.000$ inhabitants), Dourados (DOU) in Mato Grosso do Sul (MS), the state of high endemicity (27.92/100.000 inhabitants) and three municipalities of the metropolitan region of Rio de Janeiro (RJ), area of high endemicity (12.45/100.000 inhabitants).

To recruit HW for the study, a "snowball" strategy was utilized whereby a social network was used..$^{15}$ The starting point was a member of this net- work, who then indicated another or others, and so on. ${ }^{16,17}$ This type of sampling technique works as a reference chain. After observing the initial subject, the researcher asks this subject to help identify people with a similar interest.

To calculate the sample, the study took into account seropositivity studies in contacts from endemic areas $(16 \%)$, a confidence interval level of $95 \%$, allowing for a difference of $4 .^{6,18-20}$ The estimated number was 323 and 450 HW (141 doctors, 88 nurses and 221 nursing assistants) were tested in fifteen public health institutions: six health facilities (CA: 01; DOU: 01, RJ: 04) and nine general hospitals ( CA: 03; DOU: 03, RJ: 03).

Inclusion criteria considered doctors, nurses and nursing assistants with over 5 years of experience in different sectors of health units belonging to the National Health System, regardless of whether they had administered care to leprosy patients. During the interview, this experience was verified. In addition, seropositive health professionals were asked specific questions about the signs of the disease and leprosy in their relatives or close contacts, and advised to remain vigilant regarding signs and symptoms. The variables analyzed were: exposure time, age, sex, profession, place of work, if they work/worked in the leprosy assistance program (yes/no), job location and function. They used a structured questionnaire.

The ML Flow test was performed according to the methods described by Bührer Sékula et al in 2003. ${ }^{5}$ A blood sample by digital puncture was placed in the receptacle and a sample dilution solution was added. The diluted blood travels along a line of antigen and a control line. The test was read after five minutes, and the result considered valid if the control line (anti-human IgM) was clearly visible. If antibodies specific to $M$. leprae $\operatorname{IgM}$ are present, they react with the antigen (semisynthetic derivative of PGL-1 bound to BSA) and a very clear red line appears in the test zone. No staining (-) or very low $(+/)$, indicates a negative result.

The entire process of recruitment and serological tests performed were applied by the same researcher, who observed more refusals among doctors and nurses than nursing assistants. These data are not considered, but the methodology made it possible to achieve the total number intended for the sample.

Statistical analyses employed logistic regression. All variables that showed significance $<20 \%$ in the univariate analyses were each included in the multivariate analyses. Those with significance $<5 \%$ were retained in the model. 


\section{Ethics}

The study was approved by the Ethics Committee of the Oswaldo Cruz Foundation/ FIOCRUZ (547/10) in Rio de Janeiro/RJ. Prior to the interview procedures and testing, all workers had given agreement and signed a consent form, in accordance with the requirements of resolution no.196/96 of the National Health Council (NHC), which deals with the guidelines and standards involving humans. ${ }^{21}$

\section{RESULTS}

Table 1 displays the general characteristics of the HW tested. Despite the predominance of females $(69.3 \%)$, no statistical differences linked to gender were observed regarding seropositivity. There was also no difference between age groups, the type of professional and leprosy disease assistance. The representativeness of each state / municipality in a total number of HW was similar but there were differences between occupational groups in each place. Of the $450,34.9 \%$ reported that they had worked in leprosy care for over five years (53.8\% in RJ, 35.3\% in MS and $13.4 \%$ in RS) but no difference ( $p=0.266)$ in seropositivity was observed between those who worked with leprosy and those who did not (Table 1). Paradoxically, a statistical association was observed between the area studied and seropositivity, as the place with the lowest endemicity (CA) had the highest seropositivity rate $(p=0.033$, Table 1$)$.

By analyzing the professional category and seropositivity of all the HW tested (Table 1), it was discovered that nurses had the highest percentage $(20.4 \%)$, followed by auxiliary nurses $(17.2 \%)$, with no significant difference $(\mathrm{p}=0.149)$.

$16.0 \%$ seropositivity was found among health professionals and, taking into account each municipality (Table 2), the seropositivity difference between professionals was significant in RJ and DOU. Further, positivity levels were similar in the three professional categories in CA and there was no difference between them.

The univariate logistic regression analysis tested the variables of sex, age, professional category, studied area and leprosy assistance. Only the studied area and professional category presented $p<0.200$ and they were then analyzed in the multivariate analysis, which showed that the chances of positivity in CA were 2-3 times greater than in RJ, taking into account professional category $(p=0.013)$. The study also revealed that nurses and nurse assistants were at greater risk of seropositivity compared to doctors $(\mathrm{OR}=1.98)$ taking into account the area of study $(\mathrm{p}=0.070$, Table 3$)$.
TABLE 1: General characteristics of health workers submitted to serology test (ML flow) in Cruz Alta/RS, Dourados/MS and three municipalities of the metropolitan area of Rio de Janeiro, from August 2010 to June 2011

\begin{tabular}{|c|c|c|c|c|c|c|c|}
\hline \multirow[t]{2}{*}{ Variables } & \multirow[t]{2}{*}{$N(n=450)$} & \multirow[t]{2}{*}{$\%$} & \multicolumn{2}{|c|}{ Serology +} & \multicolumn{2}{|l|}{ Test } & \multirow[t]{2}{*}{ Value $p$} \\
\hline & & & $\mathbf{N}$ & $\%$ & $\mathbf{N}$ & $\%$ & \\
\hline \multicolumn{8}{|l|}{ Sex } \\
\hline \multirow{2}{*}{$\begin{array}{l}\text { Male } \\
\text { Female }\end{array}$} & 138 & 30.7 & 21 & 15.2 & 117 & 84.8 & 0.763 \\
\hline & 312 & 69.3 & 51 & 16.3 & 261 & 83.7 & \\
\hline \multicolumn{8}{|l|}{ Age group } \\
\hline $22-30$ & 163 & 36.2 & 33 & 20.3 & 130 & 79.7 & 0.299 \\
\hline $31-40$ & 114 & 25.3 & 15 & 13.2 & 99 & 86.8 & \\
\hline $41-50$ & 97 & 21.6 & 13 & 13.4 & 84 & 86.6 & \\
\hline $51-60$ & 58 & 12.9 & 10 & 17.2 & 48 & 82.8 & \\
\hline$>60$ & 18 & 4.0 & 1 & 5.6 & 17 & 94.4 & \\
\hline \multicolumn{8}{|c|}{ Area/States } \\
\hline RJ(Metrop) & 158 & 35.1 & 17 & 10.8 & 141 & 89.2 & 0.033 \\
\hline MS (Dou) & 150 & 33.3 & 24 & 16.0 & 126 & 84.0 & \\
\hline $\mathrm{RS}(\mathrm{CA})$ & 142 & 31.6 & 31 & 21.8 & 111 & 78.2 & \\
\hline \multicolumn{8}{|l|}{ Profession } \\
\hline Doctor & 141 & 31.3 & 16 & 11.3 & 125 & 88.7 & 0.149 \\
\hline Nurse & 88 & 19.6 & 18 & 20.4 & 70 & 79.6 & \\
\hline Nursing. Ass & 221 & 49.1 & 38 & 17.2 & 183 & 82.8 & \\
\hline \multicolumn{8}{|l|}{$\begin{array}{l}\text { Leprosy } \\
\text { assistance }\end{array}$} \\
\hline Yes & 157 & 34.9 & 21 & 13.4 & 136 & 86.6 & 0.266 \\
\hline No & 293 & 65.1 & 51 & 17.4 & 242 & 82.6 & \\
\hline
\end{tabular}

$\mathbf{R J}=$ Rio de Janeiro-3 municipalities of metropolitan region; $\mathbf{M S}=$ Dourados municipality; $\mathbf{R S}=$ Cruz Alta municipality

Nursing. Ass= Nursing assistants

TABLE 2: Seropositivity to ML Flow according to health workers profission and municipality in Cruz Alta/RS, Dourados/MS and three municipalities of the metropolitan area of Rio de Janeiro, from August 2010 to June 2011

\begin{tabular}{llllllll}
\hline & \multicolumn{3}{c}{ ML FLOW } & \multicolumn{3}{c}{ Total } & P value \\
Areas & $\mathbf{N}$ & $\%$ & $\mathbf{N}$ & $\%$ & $\mathbf{N}$ & $\%$ & \\
& & & & & & & \\
RJ & 4 & 7.1 & 52 & 92.9 & 56 & 100 & \\
Doctor & 1 & 3.0 & 32 & 97.0 & 33 & 100 & \\
Nurse & 12 & 17.4 & 57 & 82.6 & 69 & 100 & \\
Nursing Ass. & $\mathbf{1 7}$ & $\mathbf{1 0 . 8}$ & $\mathbf{1 4 1}$ & $\mathbf{8 9 . 2}$ & $\mathbf{1 5 8}$ & $\mathbf{1 0 0}$ & $\mathbf{0 . 0 5 0}$ \\
Sub-total (a) & $\mathbf{1 4}$ & & & & & & \\
Dou & & & & & & & \\
Doctor & 5 & 10.6 & 42 & 89.4 & 47 & 100 & \\
Nurse & 10 & 35.7 & 18 & 64.3 & 28 & 100 & \\
Nursing Ass. & 9 & 12.0 & 66 & 88.0 & 75 & 100 & \\
Sub-total (b) & $\mathbf{2 4}$ & $\mathbf{1 6 . 0}$ & $\mathbf{1 2 6}$ & $\mathbf{8 4 . 0}$ & $\mathbf{1 5 0}$ & $\mathbf{1 0 0}$ & $\mathbf{0 . 0 0 7}$ \\
CA & & & & & & & \\
Doctor & 7 & 18.4 & 31 & 81.6 & 38 & 100 & \\
Nurse & 7 & 25.9 & 20 & 74.1 & 27 & 100 & \\
Nursing Ass. & 17 & 22.1 & 60 & 77.9 & 77 & 100 & 0.768 \\
Total a+b+c & 72 & $\mathbf{1 6 . 0}$ & $\mathbf{3 7 8}$ & $\mathbf{8 4 . 0}$ & $\mathbf{4 5 0}$ & $\mathbf{1 0 0}$ & \\
\hline
\end{tabular}

RJ = Rio de Janeiro; Dou= Dourados; CA= Cruz Alta Nursing Ass.= Nursing assistant 
TABLE 3: Logistic regression of multivariate analysis with the variables associated with seropositivity in health workers in Rio de Janeiro, Mato Grosso do Sul and Rio Grande do Sul, from August 2010 to June 2011

\begin{tabular}{lll}
\hline Variable & Crude OR $(\mathbf{9 5} \% \mathrm{CI})$ & Adjusted OR $(\mathbf{9 5 \% C I )}$ \\
\hline $\begin{array}{l}\text { Profession } \\
\text { Doctors }\end{array}$ & 1.00 & \\
Nurses & $2.00(0.96 ; 4.19)$ & $1.98(0.94 ; 4.15)$ \\
Nursing Ass. & $1.62(0.87 ; 3.04)$ & $1.53(0.81 ; 2.87)$ \\
Area/States & & \\
RJ (Metrop) & 1.00 & \\
MS (DOU) & $1.58(0.81 ; 3.08)$ & $1.57(0.80 ; 3.07)$ \\
RS (CA) & $2.32(1.22 ; 4.40)$ & $2.27(1.19 ; 4.33)$ \\
\hline
\end{tabular}

Nursing Ass. = Nursing assistant

RJ (Metrop) = Rio de Janeiro (Rio de Janeiro metropolitan área); MS (DOU)= Mato Grosso do Sul (Dourados); RS (CA)= Rio Grande do Sul (Cruz Alta) $\mathrm{OR}=$ Odds Ratio; $\mathrm{CI}=$ Confidence Interval

\section{DISCUSSION}

The multifactorial causes related to leprosy infection and the explicit disease minimize the perceived risk among leprosy workers. Moreover, the idea of difficult contagion due to the low pathogenicity of the disease has been spreading all over the world, despite the high infectivity of $M$. leprae. This was reasonable given that the fear related to leprosy infection used to be distant from the actual occurrence of transmission. However, it does not justify the complete negation of the disease's infectivity or the fact that biosecurity norms are rarely discussed in leprosy health services, unlike in the tuberculosis program. ${ }^{1,2}$

The stigma associated with leprosy makes it difficult to know the actual number of health workers who contract the disease. Screening of infected HW could help enhance understanding of this issue, provide evidence and aid discussions on such a delicate subject. Taking into account the concept of systemic and organizational network, the HW can be considered a social contact with their patients, as they belong to the same network (the Health System). Some of them share the same environment (nursing assistants), especially in the public health system, which is discussed in this investigação. ${ }^{22}$ When applying the technique of snowball sampling to recruit HW for this survey, the person at the beginning of this network was generally a team member who indicated a sector to be visited and a member of this sector indicated another or others, and so on. This could explain the fact that the nursing assistants were almost twice as many as the nurses and doctors included (higher $\mathrm{n}^{\circ}$ on the team). The representativity of each state / municipality in the total number of HW was similar, but it should be mentioned that there was some bias in this sampling technique, as the cities and health infrastructure involved are not uniform. Further, the number of doctors at the university hospital of RJ, or even at the health center, is greater than those in the two other municipalities. The higher proportion of women seems to be related to their predominance in the Brazilian public health. ${ }^{23}$ Interestingly, there was no difference in terms of seropositivity and sex whereas in the literature, there are some discordant results. ${ }^{8,18,24}$

Of the $450 \mathrm{HW}$ tested, $72(16 \%)$ were positive, in accordance with other studies on seropositivity in household contacts of leprosy patients in endemic areas of Brazil, using the same serologic test. Positivity varies from $15.6 \%^{19} 20.5 \%^{18}$ and $28.6 \% .^{5}$ As reported, the risk of seropositive contacts developing leprosy can be six times higher compared with the negative samples. ${ }^{20}$ Thus, the high seropositivity found in HW tested in this study must at least be investigated. There was no difference in seropositivity among those who worked directly in support services for leprosy and those who did not. Surprisingly, it was higher among those who stated that they had never worked in leprosy services. The same result was observed in the unexpected correlation with seropositivity and endemicity of leprosy in municipalities. The area with the lowest endemicity (CA) had the highest seropositivity rate. The same result was observed in a seroepidemiological survey conducted with Brazilian schoolchildren from different Brazilian regions. ${ }^{12}$

In some countries with high endemicity, transmission and subclinical infection of leprosy occur and the disease manifests itself in individuals without known contact with any leprosy patients. ${ }^{25}$ As the source of leprosy transmission seems to be influenced highly by multibacillary (MB) cases involving systemic disease, sometimes without cardinal signs before being diagnosed, all PS are probably exposed in endemic countries. ${ }^{26}$

During this study, it was observed that the HW from CA do not have leprosy diagnosis in mind, given the low endemicity of this municipality. However, two cases of leprosy were diagnosed in CA in 2005 and later, only in 2009 , another 3 cases were reported. ${ }^{27}$

One explanation for these results may be that in areas of high endemicity, not just home contacts but the entire population is exposed to $M$. leprae. ${ }^{28}$ Moreover, health professionals understand the disease and early diagnosis is more frequent, reducing exposure time. In fact, in RS, the state of the municipality of CA, the high percentage of grade 2 disabilities in new leprosy cases is evidence of late diagnosis. ${ }^{27}$

In our results, nurses had the highest percentage $(20.4 \%)$, followed by nursing assistants $(17.4 \%)$, without any significant difference. Taking into account each municipality, the difference was significant in RJ and in DOU. However, given that all HW 
had high positivity levels in CA, there is no difference between them. Univariate analysis indicates that nurses and nursing assistants faced higher risks of seropositivity compared with physicians, as expected. Nevertheless, only nurses maintained a significant difference in a multivariate analysis. It is perfectly understandable as to why doctors from RJ had low a seropositivity rate $(7.14 \%)$ while that for nurses from DOU was higher $(35.71 \%)$. The unpredictable result appeared upon analyzing the variable isolated area. HW from RJ and DOU face lower risks of positivity compared with HW from CA, a municipality of Rio Grande do Sul, which is a state where leprosy elimination targets were met in the nineties.

Regarding known risk factors for leprosy, such as level of education, it is important to highlight that, although the seropositivity rate for nursing assistants was less than for nurses, out of all the HW, they presented high positivity across all three states. Moreover, this information should be examined in order to clarify the extremely high seropositivity in nurses from DOU, which influenced the data.

Among the factors that could explain the unexpected results found in this article, the authors suggest the presence of an unspecific bovine serum albumin (BSA) link, carrier of the antigen PGL-1 and its potential interference. ${ }^{5,29,30}$ It may be higher in areas of low endemicity, with an antibody that is less specific to anti-PGL-1. In this context, a factor that can be investi- gated concerns the consumption of bovine and, as is well-known, Rio Grande do Sul consumes the most in Brazil. $^{31,32}$ This observation is substantiated by similar results from Sjöwall and collaborators, who showed that the anti-BSA antibodies are common in rheumatoid arthritis patients and healthy persons. BSA is a common food antigen and antibodies against BSA derived from food may interfere in specific antigen results for immunoassays that use BSA as a protein carrier, which can be avoided by using human serum albumin. ${ }^{33}$ Increased levels of anti-BSA antibodies were found in autoimmune diseases such as inflammatory or auto-insulin-dependent diabetes mellitus, Crohn's disease and celiac disease, systemic lupus erythematosus and in healthy blood donors. ${ }^{34.37}$ Therefore, despite the high specificity of serological tests today, it is recommended that the tests be improved. ${ }^{38}$

\section{CONCLUSION}

The results revealed high positivity rates among health professionals, similar to those of household contacts of leprosy patients. They are higher in areas of low endemicity, regardless of direct care for leprosy patients. The authors submit that these results are associated with the presence of an unspecific link to bovine serum albumin (BSA), carrier of the antigen PGL-1 in the ML Flow test, and recommend expanded seroepidemiological research using tests with human and bovine albumin. 


\section{REFERENCES}

1. Costa J, Silva R, Sá R, Cardoso MJ, Ferreira J, Ribeiro C, et al. Tuberculosis - Risk of continued transmission in healthcare workers. Rev Port Pneumol. 2010;16:5-21.

2. Gonçalves B, Cavalini L, Valente JG. Epidemiological monitoring of tuberculosis in a general teaching hospital. J Bras Pneumol. 2010;36:347-55.

3. Bührer-Sékula S. A Simple Dipstick Assay for Leprosy: Development, Evaluation and Application [tese]. Amsterdam: Universiteit van Amsterdam; 2000. 111p.

4. Bührer-Sékula S, Visschedijk J, Grossi MA, Dhakal KP, Namadi AU, Klatser PR, et al. The ML Flow test as a point of care test for leprosy control programmes: potential effects on classification of leprosy patients. Lepr Rev. 2007;78:70-9.

5. Bührer-Sékula S, Smits HL, Gussenhoven GC, van Leeuwen J, Amador S, Fujiwara T, et al. Simple and fast lateral flow test for classification of leprosy patients and identification of contacts with high risk of developing leprosy. J Clin Microbiol. 2003;41:1991-5.

6. Douglas JT, Cellona RV, Fajardo TT Jr, Abalos RM, Balagon MV, Klatser PR. Prospective study of serological conversion as risk factor for development ofleprosy among household contacts. Clin Diagn Lab Immunol. 2004;11:897-900.

7. Lockwood DNJ, Suneetha S. Leprosy: too complex a disease for a simple elimination paradigm. Bull World Health Organ. 2005;83:230-5.

8. Fine PE, Ponnighaus JM, Burgess P, Clarkson JA, Draper CC. Seroepidemiological studies of leprosy in northen Malawi based on an enzyme-linked immunosorbent assay using synthetic glycoconjugate antigen. Int J Lepr Other Mycobact Dis. 1988;56:243-54.

9. Bührer-Sekula S, Cunha MG, Ferreira WA, Klatser PR. The use of whole blood in a dipstick assay for detection of antibodies to Mycobacterium leprae: a Field evaluation. FEMS Immunol Med Microbiol. 1998;21:197-201.

10. Bührer SS, Smits HL, Gussenhoven GC, van Ingen CW, Klatser PR. A simple dipstick assay for the detection of antibodies to phenolic glycolipid-I of Mycobacterium leprae. Am J Trop Med Hyg. 1998;58:133-6.

11. Roche PW, Failbus SS, Britton WJ, Cole R. Rapid method for diagnosis of leprosy by measurements of antibodies to the M. leprae 35-kDa protein: comparison with PGL-I antibodies detected by ELISA and "dipstick" methods. Int J Lepr Other Mycobact Dis. 1999;67:279-86

12. Bührer-Sékula S. PGL-I leprosy serology. Rev Soc Bras Med Trop. 2008;41:3-5.

13. Brasil MTLRF, Oliveira LR, Rimoli NS, Cavallari S, Gonçalves OS, Lessa ZL, et al. Sorologia Anti PGL-1 e risco de ocorrência de hanseníase em área de alta endemicidade do Estado de São Paulo: quatro anos de seguimento. Rev Bras Epidemiol. 2003;6:262-71.

14. Duthie MS, Goto W, Ireton GC, Reece ST, Cardoso LP, Martelli CM, et al. Use of Protein Antigens for Early Serological Diagnosis of Leprosy. Clin Vaccine Immunol. 2007:14:1400-8

15. Goodman LA. Snowball Sampling. An. Math Statist. 1961;32:148-70

16. Trentini CM. Qualidade de vida em Idosos [tese]. Porto Alegre (RS): Universidade Federal do Rio Grande do Sul; 2004. 224 p.

17. Castro MGT, Oliveira MS, Araujo RB, Pedroso RS. Relação entre gênero e sintomas depressivos e ansiosos em tabagistas. Rev Psiquiatr. 2008;30:25-30.

18. Andrade AR, Grossi MA, Bührer-Sékula S, Antunes CM. Seroprevalence of ML Flow test in leprosy contacts from State of Minas Gerais, Brazil. Rev Soc Bras Med Trop. 2008:41:56-9.

19. Calado KLS, Vieira AG, Durães S, Bührer-Sékula S, Oliveira MLWR. Seropositivity with anti-PGL- I of household and neighbours contacts of leprosy patients in an urban área. An Bras Dermatol. 2005;80:301-6.

20. Goulart IM, Bernardes Souza D0, Marques CR, Pimenta VL, Gonçalves MA, Goulart LR.. Risk and protective factors for leprosy development determined by epidemiological surveillance of household contacts. Clin Vaccine Immunol. 2008:15:101-5.

21. Saúde.gov.br [página da Internet]. Conselho Nacional de Sáude (CNS). Resolução CNS $n^{\circ} 196$, de 10 de outubro de 1996. Aprova as diretrizes e normas regulamentadoras de pesquisas envolvendo seres humanos. [acesso 4 dez 2012]. Disponível em: http://conselho.saude.gov.br/resolucoes/reso 9

22. Gomide M, Grossetti M. Rede social e desempenho de programas de saúde: uma proposta investigativa. Physis. 2010;20:873-93.

23. Ibge.gov.br [página na Internet]. Instituto Brasileiro de Geografia e Estatística (IBGE). Indicadores IBGE: principais destaques da evolução do mercado de trabalho nas regiões metropolitanas abrangidas pela pesquisa: Recife, Salvador, Belo Horizonte, Rio de Janeiro, São Paulo e Porto Alegre 2003-2010 Brasília: Ministério do Planejamento, Orçamento e Gestão; 2010. [acesso 04 ago 2011]. Disponível em: http://www.ibge.gov.br/home/estatistica/indicadores/trabalhoerendimento/pme_nova/r etrospectiva2003_2010.pdf

24. González-Abreu E, Pon JA, Hernádez P, Rodriguez J, Mendoza E, Hernández M, et al. Serological reactivity to a synthetic analog of phenolic glycolipid I and early detection of leprosy in an area of low endemicity. Lepr Rev. 1996;67:4-12.
25. Moet FJ, Schuring RP, Pahan D, Oskam L, Richardus JH. The Prevalence of Previously Undiagnosed Leprosy in the General Population of Northwest Bangladesh. PLoS Negl Trop Dis. 2008;2:e198.

26. Oliveira MLW, Cavaliére FAM, Maceira JMP, Bührer-Sékula S. 0 uso da sorologia como ferramenta adicional no apoio ao diagnóstico de casos difíceis de hanseníase multibacilar: lições de uma unidade de referência. Rev Soc Bras Med Trop . 2008;41 Suppl 2:27-33.

27. Saude.gov.br [página na Internet]. SINAN/SVS-MS Confirmed cases reported in the Information System for Notifiable Diseases. [acesso 05 Jul 2011]. Brasília: Ministério da Saúde; 2010. Disponível em: http://dtr2004.saude.gov.br/sinanweb/tabnet/ $\mathrm{dh}$ ?sinannet/hanseníase/bases/hansbrnet.def

28. Oskam L, Slim E, Bührer-Sékula S. Serology: Recent Developments, Strenghts, Limitations and Prospects: A State of the Art Overview. Lepr Rev. 2003;74:196-205.

29. Rodrigues LS, da Silva Maeda E, Moreira ME, Tempone AJ, Lobato LS, Ribeiro-Resende VT, et al. Mycobacterium leprae induces insulin-like growth factor and promotes survival of Schwann cells upon serum withdrawal. Cell Microbiol. 2010;12:42-54

30. Williams AJ, Curnock R, Reed CR, Easton P, Rokni S, Bingley PJ. Anti-BSA antibodies are a major cause of non-specific binding in insulin autoantibody radiobinding assays. J Immunol Methods. 2010;362:199-203.

31. Santos JS, Xavier AAO, Ries EF, Costabeber I, Emanuelli T. Animal food products intake by university students in Santa Maria/ RS. Nutrire Rev Soc Bras Aliment Nutr. 2006;31:13-24.

32. Ibge.gov.br [página na Internet]. Instituto Brasileiro de Geografia e Estatística (IBGE). POF 2008-2009: mais de 90\% da população comem poucas frutas, legumes e verduras. Brasília: Ministério do Planejamento, Orçamento e Gestão; 2011. [acesso 04 ago 2011]. Disponível em: http://www.ibge.gov.br/home/presidencia/noticias/noticia visualiza.php?id noticia $=1937 \&$ id pagina $=1$

33. Sjöwall C, Kastbom A, Almroth G, Wetterö J, Skogh T. Beware of antibodies to dietary proteins in "antigen-specific" immunoassays! falsely positive anticytokine antibody tests due to reactivity with bovine serum albumin in rheumatoid arthritis (the Swedish TIRA project). J Rheumatol. 2011;38:215-20.

34. Damiani D. Diabetes mellitus tipo 1 e os anticorpos contra albumina sérica bovina. Rev Assoc Med Bras. 2004;50:119.

35. Lerner A, Rossi TM, Park B, Albini B, Lebenthal E. Serum antibodies to cow's milk proteins in pediatric inflammatory bowel disease. Crohn's disease versus ulcerative colitis. Acta Paediatr Scand. 1989;78:384-9.

36. Mogues T, Li J, Coburn J, Kuter DJ. IgG antibodies against bovine serum albumin in humans-their prevalence and response to exposure to bovine serum albumin. J Immunol Methods. 2005;300:1-11.

37. Korenblat PE, Rothberg RM, Minden P, Farr RS. Immune responses of human adults after oral and parenteral exposure to bovine serum albumin. J Allergy. 1968;41:226-35.

38. Stefani MMA. Desafios na era pós genômica para o desenvolvimento de testes laboratoriais para o diagnóstico da hanseníase. Rev Soc Bras Med Trop. 2008;41:89-94.

How to cite this article: Calado KLS, Magnanini MMF, Moura RS, Gallo MEN, Bührer-Sékula S, Oliveira MLW. Serology with ML Flow test in health professionals from three different states of Brazil. An Bras Dermatol. 2013;88(6):918-23. 